\title{
The roles of vitamin D and cathelicidin in type 1 diabetes susceptibility
}

\author{
Cecília Cristelo ${ }^{1,2}$, Alexandra Machado 2 , Bruno Sarmento ${ }^{1,3}$ and Francisco Miguel Gama ${ }^{2}$ \\ 1i3S - Instituto de Investigação e Inovação em Saúde, Universidade do Porto, Porto, Portugal \\ ${ }^{2}$ CEB - Centro de Engenharia Biológica, Universidade do Minho, Braga, Portugal \\ ${ }^{3}$ CESPU, Instituto de Investigação e Formação Avançada em Ciências e Tecnologias da Saúde \& Instituto Universitário de Ciências da Saúde, \\ Gandra, Portugal
}

Correspondence should be addressed to F M Gama: fmgama@deb.uminho.pt

\begin{abstract}
Type 1 diabetes has an increasingly greater incidence and prevalence with no cure available. Vitamin D supplementation is well documented to reduce the risk of developing type 1 diabetes. Being involved in the modulation of cathelicidin expression, the question whether cathelicidin may be one of the underlying cause arises. Cathelicidin has been implicated in both the development and the protection against type 1 diabetes by mediating the interplay between the gut microbiome, the immune system and $\beta$ cell function. While its potential on type 1 diabetes treatment seems high, the understanding of its effects is still limited. This review aims to contribute to a more comprehensive understanding of the potential of vitamin $D$ and cathelicidin as adjuvants in type 1 diabetes therapy.
\end{abstract}
Key Words
- $\beta$ cell protection
- cathelicidin
- diabetes
- immunomodulation
- vitamin D

\section{Type 1 diabetes}

Diabetes mellitus refers to a group of metabolic diseases characterised by chronic hyperglycaemia due to absent insulin secretion, insulin action or both (1). Diabetes is classically divided in type 1 and type 2 diabetes (2) and of all individuals diagnosed with this disease, type 1 diabetes represents up to $10 \%$, of which $80-90 \%$ are children or adolescents (3). Type 1 diabetes is commonly referred to as autoimmune diabetes and results from the autoimmune destruction of pancreatic $\beta$ cells. On the other hand, type 2 diabetes, which accounts for the remaining $90 \%$ of cases, affects mostly adults, although its incidence in youth is increasing due to changes in lifestyle and increased obesity (4). Differently from type 1 diabetes, type 2 diabetes is characterised by insulin resistance and defective insulin secretion, which may be accompanied by the destruction of $\beta$ cells (5).

Type 1 diabetes is one of the most common endocrine diseases in children (6); recent reports indicate a yearly increase from 3 to $4 \%$ on the incidence in childhood (7).
This is most concerning in children with less than 15 years and particularly less than 5 years (8).

Type 1 diabetes is a multifactorial disease. Genetic factors associated with certain haplotypes from the HLA complex have been shown to decisively influence the susceptibility (9). Additionally, environmental factors such as the seasonal environment at birth (3), infant diet (10), viral infections (11) and the gut microbiome (12) have also been suggested to play a role on type 1 diabetes development. The heterogeneity and variation in the pathogenic process and phenotypic characteristics makes it difficult to diagnose and to treat the disease at an early stage (13).

\section{Pathophysiology}

Type 1 diabetes is a chronic disease resulting from the autoimmune destruction of the insulin-producing $\beta$ cells in the pancreas. Not all cases of type 1 diabetes are autoimmune mediated. For around $10-30 \%$ of patients,
This work is licensed under a Creative Commons Attribution-NonCommercial 4.0 International License. ded from Bioscientifica.com at 04/26/2023 12:12:34PM 
the cause is idiopathic and the specific pathogenesis is unclear (14).

The triggering event that leads to the autoimmune elimination of $\beta$ cells is still unknown but may be related to a failure in the elimination of self-reactive $\mathrm{T}$ cells, in the thymus. This leads to the escape of $\mathrm{T}$ cell populations - autoreactive against $\beta$ cell proteins such as insulin, glutamic acid decarboxylase (GAD) and protein tyrosine phosphatase IA-2 - to the periphery $(15,16,17)$. Upon encounter with the self-antigens, $T$ cells undergo activation and expansion, releasing proinflammatory cytokines. This promotes pancreatic infiltration of more T cells, macrophages, B lymphocytes and plasma cells, with resultant autoimmune destruction of the insulin-secreting $\beta$ cells (18). The symptoms are observed only when around two-thirds of the $\beta$ cell mass is lost (19). During the presymptomatic stage, markers of autoimmunity, presence of islet autoantibodies in circulation, as well as dysregulation of blood glucose start to arise due to the loss of $\beta$ cells. With the continuous decline in $\beta$ cells, the symptomatic stage is reached and signs of diabetes, polyuria, polydipsia, weight loss, fatigue, diabetic ketoacidosis (DKA) are identified (20). The rate of progression to the symptomatic stage can vary from months to decades, in both children and adults (13).

\section{Type 1 diabetes management strategies}

Given the absence or reduced insulin secretion, an obvious strategy for type 1 diabetes management involves its exogenous administration (21). Since the discovery of insulin in 1922, much advances in health care has been achieved, such that the previously terminal disease is now treatable. Nowadays, the availability of new insulin analogues, with varying duration of activity, allows for a multiple-dose insulin therapy that better resembles the physiologic insulin release (22). The combination of the rigorous monitoring of blood glucose levels with the multifunctional insulin therapy enables the glycaemic control, and to prevent, or delay, the complications of type 1 diabetes (23).

Despite these advances, type 1 diabetes is still associated with a high medical, psychological and financial burden. Hypoglycaemia and ketoacidosis remain life-threatening complications, as well as an increased risk of co-morbidities (cardiovascular disease, retinopathy and nephropathy) and premature death $(22,24)$.

Efforts to manage the disease are not able to reach a cure but only a control of the symptoms. Given the heterogeneity of type 1 diabetes, treatment should also be looked as a multivalent strategy. Alternative strategies have been explored, including the use of immunosuppressant therapies, which leave the patients immunocompromised and susceptible to infections; the use of antigenic tolerance therapies, the protection of $\beta$ cells and selective stimulation of their proliferation or reprograming of non- $\beta$ cells into functional $\beta$ cells (19). Although islets have limited regenerative capacity it has been found that, within islets, $\alpha$ cells and $\delta$ cells can undergo transdifferentiation to functional $\beta$ cells or $\beta$-like cells $(25,26)$. Pancreatic $\beta$ cells replicate at a high rate during the foetal and neonatal stages, a process that rapidly declines with age (27). Inducing $\beta$ cells to undergo mitosis using harmine and 5-iodotubercidin, inhibitors of the dual-specificity tyrosine phosphorylation-regulated kinase 1A (DYRK1A), has shown promising to the recovery of $\beta$ cell mass $(28,29)$. However, the limited potency and lack of $\beta$ cell specificity, with undesirable off-target effects, limit their applicability. A drug able to stimulate $\beta$ cell regeneration while simultaneously shifting the proinflammatory autoimmune islet milieu to an antiinflammatory one, to prevent future insulitis, would be the ideal candidate for type 1 diabetes cure (19).

Vitamin D and the antimicrobial peptide cathelicidin have been proposed as promising candidates for this endeavour. On one hand, both pre-clinical and clinical research demonstrated vitamin $\mathrm{D}$ has a well-established role in the protection from type 1 diabetes development. On the other hand, although cathelicidin expression is directly induced by vitamin $\mathrm{D}$, the mechanistic effects of cathelicidin in type 1 diabetes susceptibility and therapy are still poorly understood.

\section{Vitamin D}

Vitamin $\mathrm{D}_{3}$ (cholecalciferol, hereafter mentioned as $\mathrm{D}_{3}$ ) is a liposoluble molecule precursor of human steroid hormones, which can be obtained through diet or exposure to UV-B sunlight. After production, $\mathrm{D}_{3}$ is partially stored in adipose tissues in a few hours, while other part is converted to 25-hydroxyvitamin $\mathrm{D}_{3}\left(25(\mathrm{OH}) \mathrm{D}_{3}\right)$ by the liver. $25(\mathrm{OH}) \mathrm{D}_{3}$ is further hydroxylated into the active form 1,25-dihydroxyvitamin $\mathrm{D}_{3}\left(1,25(\mathrm{OH})_{2} \mathrm{D}_{3}\right)$ in the kidneys (30), which then acts to maintain serum calcium levels, although its activities go beyond calcium homeostasis and bone metabolism (31).

The vitamin D receptor (VDR) has been identified in practically all immune cell types (32). After intracellular enzymatic activation of vitamin D and subsequent VDR 


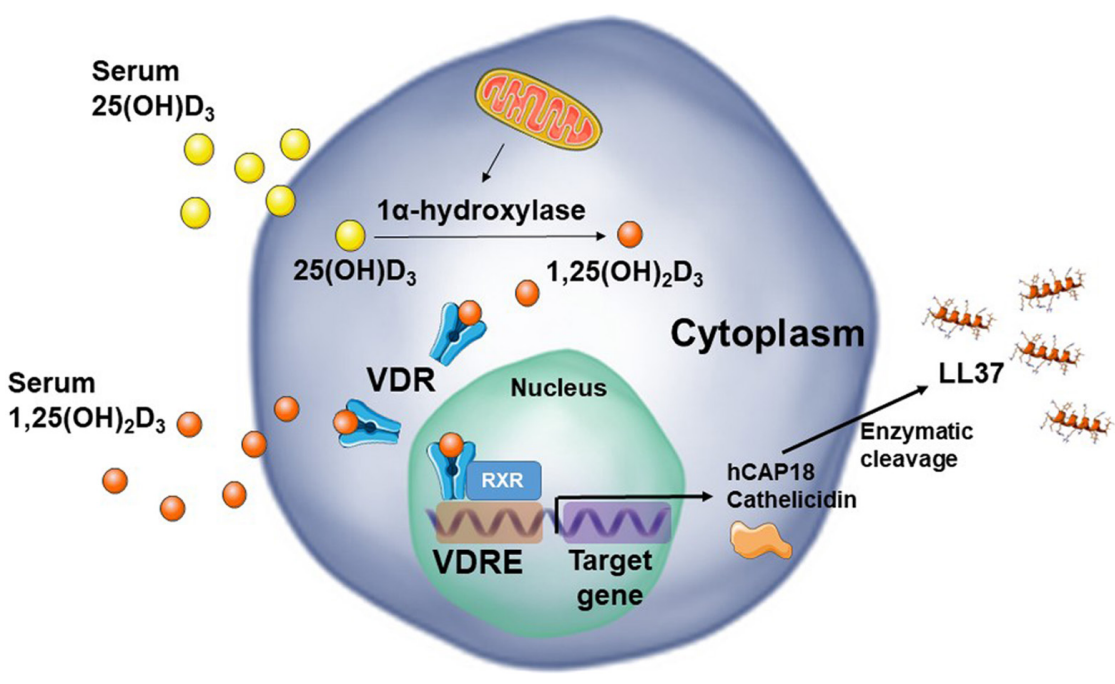
Figure 1
Classic vitamin $\mathrm{D}$ signalling pathway. Serum $25(\mathrm{OH}) \mathrm{D}_{3}$ is converted to $1,25(\mathrm{OH})_{2} \mathrm{D}_{3}$ by mitochondrial $1 \alpha$-hydroxylase, initiating the signalling cascade by binding to VDR, which dimers with RXR, and binds to specific DNA sequences, VDREs, regulating the transcription of several genes. 1,25(OH) $)_{3}$-VDR-RXR complex then synthesizes cathelicidin as an inactive pro-peptide (hCAP18) which is cleaved upon release of the active LL-37 by proteases.

binding, dimerisation with retinoid $\mathrm{X}$ receptor (RXR) induces gene transcription at specific DNA sequences, termed vitamin D response elements (VDRE) (Fig. 1). $1,25(\mathrm{OH})_{2} \mathrm{D}_{3}$, a potent pleiotropic hormone, acts as a molecular switch targeting hundreds of known human genes across a wide variety of tissues, including the human cathelicidin which will be later discussed (33). Many cell types are able to co-express VDR and the $25(\mathrm{OH}) \mathrm{D}_{3}$-activating enzyme, $1 \alpha$-hydroxylase, including macrophages, dendritic cells and $\beta$ cells, enabling the intracrine metabolism and action of $1,25(\mathrm{OH})_{2} \mathrm{D}_{3}$ generated from $25(\mathrm{OH}) \mathrm{D}_{3}(34,35)$.

\section{Immunomodulatory roles of vitamin $D$ in type 1 diabetes}

Vitamin D has the ability to downregulate adaptive immunity and induce immunological tolerance and antiinflammatory effects, being significant in the context of autoimmune diseases. The immunomodulatory effects of $1,25(\mathrm{OH})_{2} \mathrm{D}_{3}$ with particular relevance for type 1 diabetes are presented in Fig. 2. $1,25(\mathrm{OH})_{2} \mathrm{D}_{3}$ exerts immunomodulatory effects in the interplay between dendritic cells (DCs), macrophages, T CD8+ (cytotoxic), T CD4+ (helper) and B lymphocytes.

In the context of type 1 diabetes, $\mathrm{T}$ CD8+ cells bearing a self-reactive $\mathrm{T}$ cell receptor can recognise selfantigens present on $\beta$ cell surface, on MHC I, inducing apoptosis of the $\beta$ cell through perforin or Fas/Fas ligand interactions. These self-antigens can also be picked up by resident or recruited DCs or macrophages which present these antigens to T CD4+ cells. In turn, these T cells may then directly kill the nearby $\beta$ cells, initiate the immune response producing soluble mediators that induce $\beta$ cell death or recruit other immune cells to the pancreas which further damage the $\beta$ cells (36). 1,25(OH) ${ }_{2} \mathrm{D}_{3}$ inhibits the differentiation, activation and maturation of DCs as well as the expression of MHC II $(37,38,39)$, decreasing autoantigen presentation and, thus, preventing the first step in the initiation of an immune response. Additional effects on DCs include downregulation of proinflammatory IL-12 and TNF $\alpha$, and simultaneous upregulation of anti-inflammatory IL-10, TGF $\beta$ and stimulation of immunosuppressive T-reg cells $(40,41$, 42). $1,25(\mathrm{OH})_{2} \mathrm{D}_{3}$ can also inhibit the differentiation of monocytes into macrophages and the activation of $\mathrm{T}$ CD8+ cells $(43,44)$.

The presentation of the antigens by DCs and macrophages to $\mathrm{T} C \mathrm{CD} 4+$, leads to their differentiation into T helper (Th) 1 and Th17, which further stimulate IL-12 and IFN $\gamma$ production, consequently improving T CD8+ and macrophage attack to $\beta$ cells. By decreasing the IL-12 secretion required for $\mathrm{T}$ CD4+ activation and stimulating the release of IL-10, $1,25(\mathrm{OH})_{2} \mathrm{D}_{3}$ inhibits the proliferation, activation and differentiation of TCD4+ cells and enhances the prevalence of T-regs. Furthermore, the activation of T-regs promotes the downregulation of proinflammatory Th1 cytokines and favours anti-inflammatory Th2 cytokines (45), diminishing type 1 diabetes progression. The presence of $1,25(\mathrm{OH})_{2} \mathrm{D}_{3}$ was reported to decrease IL-22-expressing CD4+ T cells and IFN $\gamma$ accompanied by an increase in IL-4 levels (46). Likewise, $1,25(\mathrm{OH})_{2} \mathrm{D}_{3}$ effects on macrophages include the shift from a proinflammatory profile to an anti-inflammatory one, by downregulating proinflammatory mediators, such as IL- $1 \alpha$, IL-1 $\beta$, IL- 6 and TNF- $\alpha(47,48)$, and increasing IL-10 production (49).

Following the initiation of the autoimmune process in type 1 diabetes, a further humoral reaction is triggered by $\mathrm{B}$

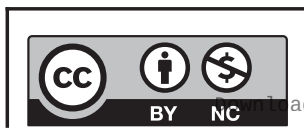




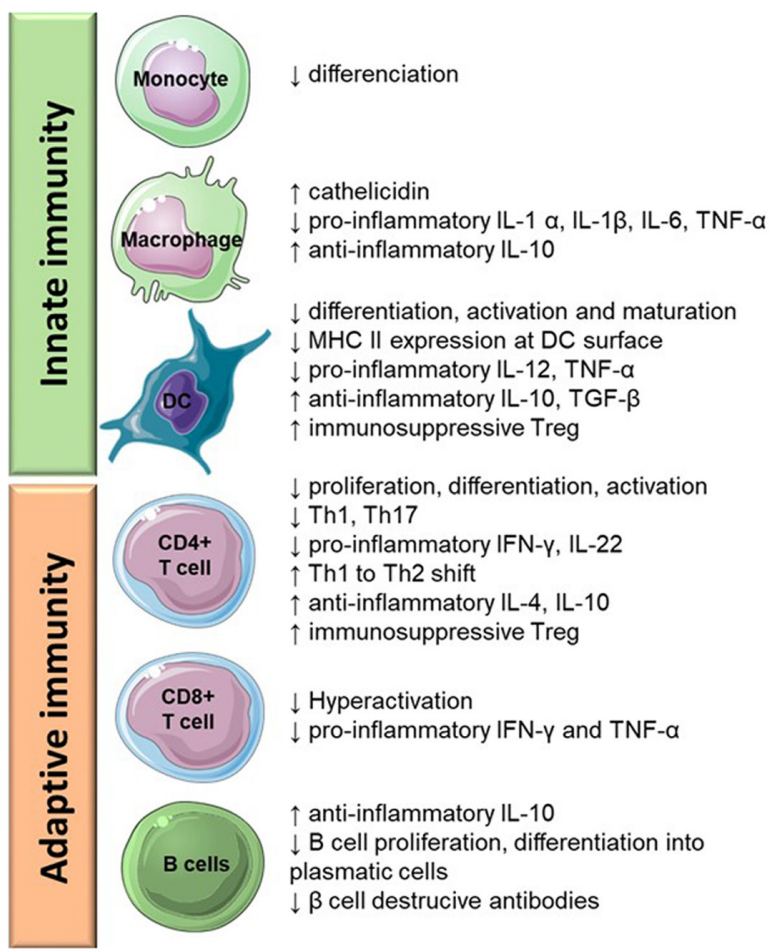

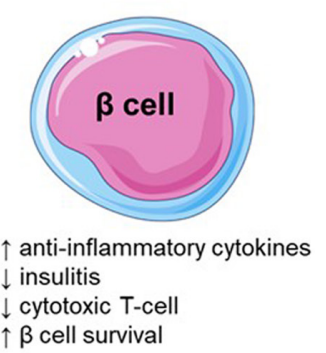

Figure 2

Immunomodulatory actions of $1,25(\mathrm{OH})_{2} \mathrm{D}_{3}$ in innate and adaptive immunity. lymphocytes that differentiate into plasma cells and secrete antibodies that contribute to $\beta$ cell destruction. $1,25(\mathrm{OH})_{2} \mathrm{D}_{3}$ inhibits B lymphocyte differentiation and proliferation $(50,51)$, consequently reducing destructive antibodies. $1,25(\mathrm{OH})_{2} \mathrm{D}_{3}$ enhances IL-10 expression by activated B lymphocytes by more than threefold, mostly by recruiting the VDR to the promoter of IL-10 (52). Drozdenko et al. further showed that $1,25(\mathrm{OH})_{2} \mathrm{D}_{3}$-primed B cells display an impaired capacity to activate T cells (53). Overall, vitamin D exhibits a protective effect on $\beta$ cells survival, which ultimately delays type 1 diabetes progression.

\section{Vitamin D role in diabetes prevention and treatment from pre-clinical to clinical evidence}

The NOD mice model opened doors to several in vivo evidences on vitamin D potential as an adjuvant for both prevention and treatment of type 1 diabetes. Mathieu et al. long ago reported that treatment with $1,25(\mathrm{OH})_{2} \mathrm{D}_{3}$ not only reduced insulitis incidence, but more importantly, also reduced the cumulative incidence of diabetes (54). Short treatment of NOD mice with Ro 26-2198, a $1,25(\mathrm{OH})_{2} \mathrm{D}_{3}$ analogue, inhibited IL-12 production, blocked pancreatic infiltration of Th1 cells and arrested the progression of type 1 diabetes (55). Vitamin D deficiency plays a determining role by increasing the incidence of diabetes in female NOD mice from 46 to $88 \%$ and from
0 to $44 \%$ in male mice, when compared to vitamin D sufficient animals (56). Additionally, oral administration of $1,25(\mathrm{OH})_{2} \mathrm{D}_{3}$ significantly delayed disease onset, although also causing a significant rise in calcium serum levels. Furthermore, mice lacking a functional VDR exhibited impaired insulin secretory capacity compared to controls (57). In another study, vitamin D privation increased type 1 diabetes incidence and glucose intolerance (58), a precocious disease manifestation, suggesting a role of vitamin $\mathrm{D}$ in slowing down the development of type 1 diabetes. Concordantly, the lifelong oral administration of high doses of $1,25(\mathrm{OH})_{2} \mathrm{D}_{3}$ safely prevented diabetes in NOD mice, both female and male, resulting in a decrease in cytotoxic $\mathrm{T}$ cells and an increase of T-regs, reducing severe insulitis and improving $\beta$ cell function (59).

Compelling evidence from pre-clinical data encouraged the search for a clinical proof of concept. Serum $25(\mathrm{OH}) \mathrm{D}_{3}$ levels depend on many factors such as region, gender, season and age, normally in the 30-68 $\mathrm{ng} / \mathrm{mL}$ range, whereas concentrations $<20 \mathrm{ng} / \mathrm{L}$ are considered deficient (60). Several studies have reported significantly lower levels of $25(\mathrm{OH}) \mathrm{D}_{3}$ in type 1 diabetes subjects compared to healthy controls $(61,62,63)$, even in an environment of abundant sunlight (64). In the last 20 years, many clinical studies have been performed on the use of vitamin $\mathrm{D}$ and derivatives as supplements to insulin in type 1 diabetes patients.
This work is licensed under a Creative Commons Attribution-NonCommercial 4.0 International License. ded from Bioscientifica.com at $04 / 26 / 2023$ 12:12:34PM via free access 
In a preventive context, $\mathrm{D}_{3}$ supplementation in children with $\geq 2000$ IU daily has shown to reduce by $80 \%$ the risk of developing type 1 diabetes (65). Moreover, a meta-analysis of observational studies showed that in at least five reports vitamin D intake during early childhood is significantly associated with a reduced risk of type 1 diabetes (66). $\mathrm{D}_{3}$ supplementation, with doses ranging from $2000 \mathrm{IU} /$ day to $4000 \mathrm{IU} /$ day, has been shown to decrease HbA1c (glycated haemoglobin) levels, while increasing T-regs and C-peptide levels (a marker of insulin secretion) $(67,68,69)$. In an attempt to avoid adverse effects, $0.25 \mu \mathrm{g}$ of $1,25(\mathrm{OH})_{2} \mathrm{D}_{3}$ administered on alternate days for 1 year along with regular insulin therapy showed a modest effect on residual pancreatic $\beta$ cell function and reduced the required insulin dose, although temporarily (70). Nevertheless, the same regimen has also been reported by others to have no beneficial effects of $\beta$ cell function and insulin requirements $(71,72)$.

New analogues, with structural modifications and non-calcemic, are emerging and may help to overcome the issue of dosage limits. One of them, alfacalcidol ( $1 \alpha$-hydroxycholecalciferol) has been shown to protect $\beta$ cell function at a dose of $0.25 \mu \mathrm{g}$ twice daily, as observed by a raise in C-peptide levels in children (73). Long-term treatment using this analogue appears to be safe and is likely to reduce the risk of hypercalcemia, as compared to $1,25(\mathrm{OH})_{2} \mathrm{D}_{3}$ administration. Other analogues tested in humans have shown higher efficacy, namely BXL-219 (formally Ro 26-2198) (74) and TX527 (75). Nevertheless, high serum calcium may be avoided not only by using analogues. Sixth-month supplementation with the precursor $25(\mathrm{OH}) \mathrm{D}_{3}$ in young patients, with increasing dosage, was reported to safely restore and maintain $25(\mathrm{OH}) \mathrm{D}_{3}$ levels up to 1 year after treatment; peripheral blood mononuclear cell reactivity against $\beta$ cell autoantigens was reduced with no significant decrease of $\beta$ cell function (76). The ability of immune cells to locally convert $25(\mathrm{OH}) \mathrm{D}_{3}$ into $1,25(\mathrm{OH})_{2} \mathrm{D}_{3}$, may support the use of this vitamin $\mathrm{D}$ metabolite over its analogues.

Altogether, vitamin D deficiency significantly increases the susceptibility to type 1 diabetes and its supplementation may improve glycaemic control. Vitamin D is an inexpensive and readily available candidate for autoimmune therapy. In addition to $1,25(\mathrm{OH})_{2} \mathrm{D}_{3}$-induced downregulation of cytokine/ chemokine production, stimulation of cathelicidin gene expression represents another very important pathway by which vitamin D regulates the innate immune response. Patients with $25(\mathrm{OH}) \mathrm{D}_{3}$ blood levels under $20 \mathrm{ng} / \mathrm{mL}$ may be unable to fully express cathelicidin (77), which could lead to increased susceptibility to type 1 diabetes.

\section{Cathelicidin}

Cathelicidins are small cationic peptides, with a size varying from 12 to 80 amino acid residues (78), expressed in many different species of mammals, the best-characterised are the human (LL-37), mouse and rat cathelicidin-related antimicrobial peptide (mCRAMP and rCRAMP). These naturally occurring antimicrobial peptides (AMPs) display a plethora of activities and a fundamental role in the innate immune system $(79,80)$.

AMPs are evolutionarily conserved molecules of the innate immune system present in all complex organisms (81). As many other AMPs, cathelicidin has a modest antimicrobial activity against a broad range of pathogens including fungi, bacteria, enveloped viruses and protozoa (82). AMPs have a small size, 37 residues in the case of LL-37, being generally cationic due to the excess of lysine and arginine residues. This feature combined with the presence of around 50\% hydrophobic residues favours interaction with the negatively charged membrane of bacteria which lead to its disruption (83).

In humans, cathelicidin is synthesized as a preproprotein, the human cathelicidin antimicrobial protein (hCAP18), which must be cleaved by serine proteases upon its exocytosis to become the active LL-37 (Fig. 1) (84).

Cathelicidin has a broad range of activities, with a pleiotropic role in innate immune responses and inflammation. It has an important immunomodulatory activity (79), with anti and proinflammatory effects in different cells, according with the inflammatory environment (85), being chemoattractant for leucocytes (86), and also being involved in tissue healing, revascularisation, cell proliferation and differentiation (80).

\section{Vitamin $D$ and cathelicidin partnership in type 1 diabetes}

The expression of LL-37 is directly induced by vitamin $\mathrm{D}(87,88)$ (Fig. 1), suggesting that the beneficial effect from vitamin D supplementation may be connected to a restoration of cathelicidin levels and raising the question whether a deficiency in LL-37 may be one of the underlying causes for type 1 diabetes susceptibility.

Positive correlation between circulating cathelicidin and $25(\mathrm{OH}) \mathrm{D}$ levels in healthy adults has been 

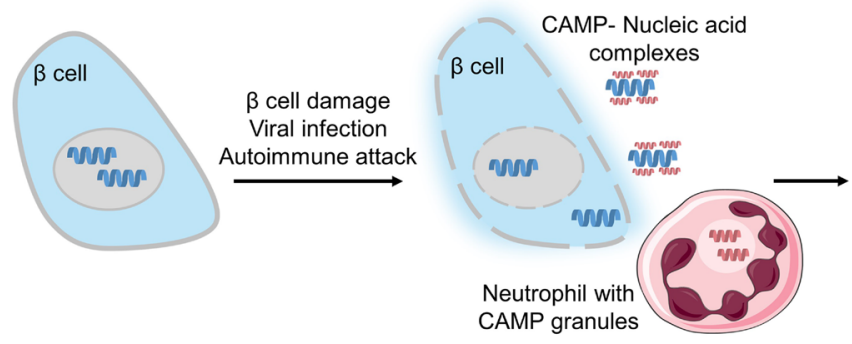

demonstrated (89). Exogenous administration of cathelicidin to increase serum levels is hampered by toxicity risks, however, vitamin D supplementation may be used as a strategy to indirectly increase LL37 serum levels.

To the best of our knowledge, no information is available on the clinical interplay between vitamin $\mathrm{D}$, LL-37 concentration and disease severity in patients with type 1 diabetes. This topic has been relatively unexplored so far in pre-clinical studies probably because the pathway by which $1,25(\mathrm{OH})_{2} \mathrm{D}_{3}$ regulates the expression of cathelicidin gene is restricted to humans and other non-human primates. Since mice and other experimental animal models lack the VDRE in their cathelicidin gene promoters $(90,91)$, in vivo studies on this topic using mice would have limited significance.

Nevertheless, Zhou et al. (92) showed that $25(\mathrm{OH}) \mathrm{D}_{3}$ attenuates periodontitis by promoting the expression of cathelicidin in mice with type 2 diabetes, however, this may have resulted from an indirect immunomodulatory effect of vitamin D on intracellular signalling.

Recently, a transgenic mice that carries a genomic DNA fragment encompassing the entire human CAMP gene was generated (93). In this study, topically applied $1,25(\mathrm{OH})_{2} \mathrm{D}_{3}$ induced CAMP expression and boosted Staphylococcus aureus killing. In the future, humanised mice may help to elucidate the biologic role of cathelicidin and vitamin $\mathrm{D}$ in type 1 diabetes.

\section{Controversial role of cathelicidin role in type 1 diabetes development vs treatment}

The intriguing role of cathelicidin in the pancreas was uncovered only recently. Diana et al. (94) hypothesised that in NOD mice, mCRAMP is involved in the initial stages of type 1 diabetes development. The authors demonstrated that, in young female NOD mice, the infiltration of innate immune cells, including neutrophils able to secrete cathelicidins, occurs as early as 2 weeks of age. If $\beta$ cell damage has occurred, self-DNA can be present extracellularly and through electrostatic interactions with cathelicidin may

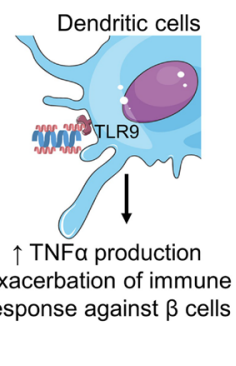

\section{Figure 3}

CAMP involvement in type 1 diabetes development in NOD mice. After a triggering event, which induces $\beta$ cell damage, the release of self-nucleic acids may occur. The presence of neutrophils in the pancreatic tissue, which releases the CAMP, may result in immune complexes which activate dendritic cells via the toll-like receptor (TLR9) and enhancing the production of proinflammatory cytokines such as TNF $\alpha$ which exacerbate the immune response against $\beta$ cells.

form immune complexes able to activate macrophages and DCs via the toll-like receptor 9 (TLR9). This exacerbates the immune response by stimulating the release of IFN- $\alpha$ which can be deleterious, as observed in other autoimmune conditions $(95,96)$ and possibly initiating the inflammatory milieu of type 1 diabetes (94) (Fig. 3).

However, in different reports, the serum concentration of LL-37 has been shown to be reduced in patients with type 1 diabetes, as compared to that of healthy subjects (97, 98) and although not significantly different, this finding suggests another role of cathelicidin in type 1 diabetes. Later, it was found that mCRAMP is also secreted by islets of various strains of mice, the ones of NOD mice secreting the lowest amounts (99). In healthy $\alpha$ and $\beta$ cells, from both human and mice islets, cathelicidin is expressed and secreted constitutively, being scarce in female NOD mice, which are most susceptible to type 1 diabetes development (99). The role of LL-37 appeared even more relevant since the intraperitoneal administration of mCRAMP led to a change in the pancreatic immune infiltrate, increasing the relative abundance of M2 macrophages and T-regs. Given that an immunosuppressive phenotype is inversely associated with type 1 diabetes risk, cathelicidin treatment resulted in a lower incidence of autoimmune diabetes in NOD mice (99). Concordantly, diabetes-prone rats which were fed with a protective-diet that delayed the onset of type 1 diabetes, showed an increased expression of cathelicidin in the epithelial lining of the small intestine and an increase in the relative abundance of M2-macrophages (100). Sun et al. (99) also demonstrated that CRAMP expression in the islets was inducible and dependent on short-chain fatty acids (SCFA), in particular butyrate, which in mammals are produced by bacteria of the gut during the fermentation of dietary fibres, thus establishing cathelicidin as a link between the gut microbiome and immune-regulation of the pancreatic immune environment (Fig. 4).

The mechanisms by which cathelicidins are produced in the islets and modulate type 1 diabetes development were further unveiled by Sun et al. (101). In this study, the authors showed that rCRAMP is constitutively expressed

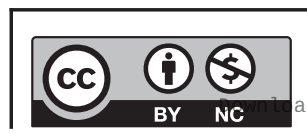

This work is licensed under a Creative Commons Attribution-NonCommercial 4.0 International License. ded from Bioscientifica.com at 04/26/2023 12:12:34PM 


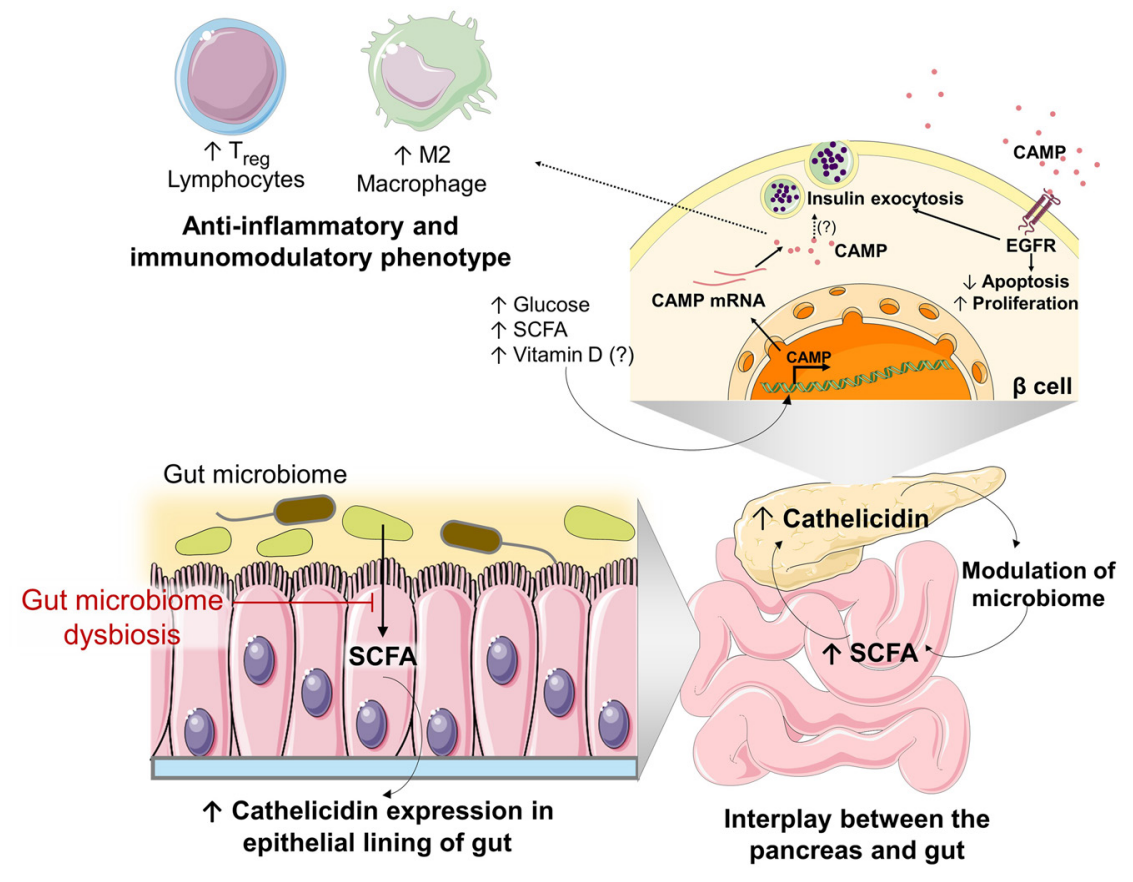

\begin{abstract}
Figure 4
Model summarising the role of cathelicidin in the interplay between the pancreas and the gut. Short-chain fatty acids (SCFA) are produced by the gut microbiome during alimentary fibre fermentation, stimulating the expression of cathelicidin in the epithelial lining of the gut. SCFA stimulates the expression of cathelicidin by pancreatic islets, which reciprocally control and modulate the bacterial growth in the gut, preventing gut microbiome dysbiosis. Cathelicidin expression in the $\beta$ cell is also induced in the presence of high glucose concentration and may also be induced by vitamin $D$, as seen in other cell types. Extracellular cathelicidin stimulates insulin granule exocytosis via the epidermal growth factor receptor (EGFR). It is not completely elucidated if intracellular cathelicidin can also induce insulin release directly. Cathelicidin expression also induces the prevalence of regulatory T cells (T-regs) and M2 macrophages which are associated with a lower risk of type 1 diabetes development.
\end{abstract}

in the INS-1 832/13 insulinoma cell line ( $\beta$ cell model), promoting cell viability and growth via the EGFR, by increasing the expression of anti-apoptotic proteins and by modulating the cleavage of caspase, overall protecting $\beta$ cells from apoptosis. Furthermore, pre-treatment with an EGFR inhibitor only partially blocked the cathelicidin stimulatory effect on cell viability, suggesting that the peptide may also act on $\beta$ cells through other receptors (101). Importantly, it was observed that cathelicidin promoted the glucose-stimulated insulin release in isolated rat and mouse islets and improved the glucose tolerance in NOD mice (101) (Fig. 4).

In a report by Pound et al. (102), the expression of cathelicidin was also detected in $\beta$ cells of rats, mice and human islets, but not on $\alpha$ cells, contrary to what was previously stated (99). In bio-breeding diabetesprone (BBdp) rats, downregulation of rCRAMP mRNA of approximately $60 \%$, was observed before the onset of insulitis, again suggesting a connection of cathelicidin with diabetes susceptibility (102). The glucoregulatory effect was further demonstrated in isolated islets in which cathelicidin treatment promoted a significant increase in insulin or glucagon secretion, in a glucose-dependent manner. Reciprocally, cathelicidin expression was also induced after exposure to higher glucose concentration (16.7 mM) (Fig. 4), which suggests a role of cathelicidin in islet paracrine signalling that enhances islet function and glucoregulation (102). Notably in in vivo studies, the treatment of BBdp rats with rCRAMP showed shortterm (after a single administration) insulin release profile comparable to that of BB control rats and long term (1-week, daily administrations) enhancing $\beta$ cell neogenesis from pancreatic duct cells (102). Since type 1 diabetes patients have a significant loss of $\beta$ cell mass, the ability to enhance $\beta$ cell regeneration and function could be therapeutically valuable (102). Additionally, cathelicidin expression was found to be downregulated in the gut of BBdp rats, which showed a clear shift in abundance of populations of gut microbiota, effects that were partially normalized by treatment with rCRAMP (102) (Fig. 4).

Further connection between cathelicidin and the microbiome was demonstrated by Ahuja et al. (103) in mice knocked-out for a calcium channel (Orai1), dampening the release of AMPs to the gut by the acinar cells from the exocrine pancreas. This allows bacteria outgrow and dysbiosis, intestinal inflammation, systemic infection and death, effects that can be prevented by mCRAMP supplementation, restoring the phenotype of Orai1-deficient mice (103). These studies reveal once more a close relationship between the pancreas and the intestine. Disturbing this balance can cause predisposition to pancreatic and intestinal diseases (104).

Deng et al. (105) showed that cathelicidin is also implicated in the protection against acute pancreatitis (AP). Immune cell infiltration, release of inflammatory mediators and apoptosis of pancreas acinar cells are characteristic of AP, which can evolve to diabetes depending on the severity and extent of pancreatic necrosis (106). In mice in which the cathelicidin gene was knocked-out, the severity of drug-induced AP was higher, with greater

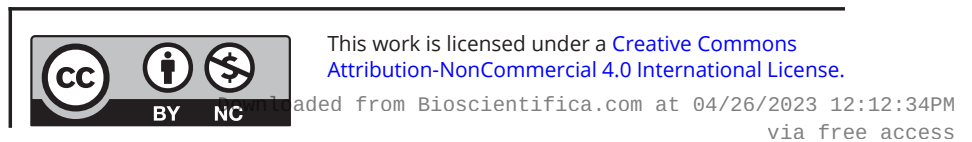


neutrophil infiltration, a more pronounced acinar cell injury and an increased production of proinflammatory cytokines, relative to the wild-type mice, showing that the anti-inflammatory effects of cathelicidin protect mice from AP (105).

With the exception of a recent report by Stenwall et al. (107), in recent years this topic was not further explored. In this study, the expression of several AMPs in the exocrine and endocrine pancreas of healthy and diabetic patients was evaluated and the presence of cathelicidin in the islets was detected using immunohistochemistry. These authors also reported a generally lower level of antimicrobial peptides in the pancreas of a type 1 diabetes donor (107).

Overall, these reports indicate that the absence of cathelicidin is associated with a higher risk of pancreatic inflammation and type 1 diabetes. Consistently, its administration seems to improve $\beta$ cell function, normalise microbiome imbalances and reduce the inflammatory response. Therefore, its potential applicability in type 1 diabetes therapy is promising, although further studies are required.

\section{Concluding remarks}

Vitamin D as well as cathelicidin have been implicated in both type 1 diabetes susceptibility and protection. Although the role of vitamin $\mathrm{D}$ has been subject to a more extensive research, the role of cathelicidin and the mechanistic effects by which its expression from $\beta$ cells may help prevent type 1 diabetes still need further exploration. The main results revised in this state of the art suggest that cathelicidin may mediate the interplay between the gut microbiome, the immune system, $\beta$ cell function and type 1 diabetes development and that the serum vitamin D may modulate those activities. Further studies are required to understand whether cathelicidin may be therapeutically valuable in type 1 diabetes.

\section{Declaration of interest}

The authors declare that there is no conflict of interest that could be perceived as prejudicing the impartiality of this review.

\section{Funding}

This work was financed by FEDER - Fundo Europeu de Desenvolvimento Regional funds through the COMPETE 2020 - Operacional Programme for Competitiveness and Internationalization (POCI), Portugal 2020, and by Portuguese funds through FCT - Fundação para a Ciência e a Tecnologia/ Ministério da Ciência, Tecnologia e Ensino Superior in the framework of the project PTDC/MED-OUT/30466/2017 and 'Institute for Research and Innovation in Health Sciences' (FCT - UID/BIM/04293/2019). Cecília Cristelo and Alexandra Machado would like to thank to Fundação para a Ciência e a Tecnologia (FCT), Portugal for financial support (SFRH/BD/139402/2018 and SFRH/BD132000/2017, respectively).

\section{Author contribution statement}

C C and A M drafted the manuscript. B S and F M G designed the topic of research and topics to discuss. All authors critically revised and approved the manuscript.

\section{References}

1 Kharroubi AT \& Darwish HM. Diabetes mellitus: the epidemic of the century. World Journal of Diabetes 20156 850-867. (https://doi. org/10.4239/wjd.v6.i6.850)

2 American Diabetes Association. Diagnosis and classification of diabetes mellitus. Diabetes Care 201437 81-87. (https://doi. org/10.2337/dc14-S081)

3 Maahs DM, West NA, Lawrence JM \& Mayer-Davis EJ. Epidemiology of type 1 diabetes. Endocrinology and Metabolism Clinics of North America 201039 481-497. (https://doi.org/10.1016/j.ecl.2010.05.011)

4 Kraemer FB, Ginsberg HN, Gerald M \& Reaven MD. Demonstration of the central role of insulin resistance in type 2 diabetes and cardiovascular disease. Diabetes Care 201437 1178-1181. (https:// doi.org/10.2337/dc13-2668)

5 Druet C, Tubiana-Rufi N, Chevenne D, Rigal O, Polak M \& LevyMarchal C. Characterization of insulin secretion and resistance in type 2 diabetes of adolescents. Journal of Clinical Endocrinology and Metabolism 200691 401-404. (https://doi.org/10.1210/jc.2005-1672)

6 Katsarou A, Gudbjornsdottir S, Rawshani A, Dabelea D, Bonifacio E, Anderson BJ, Jacobsen LM, Schatz DA \& Lernmark A. Type 1 diabetes mellitus. Nature Reviews: Disease Primers 20173 17016. (https://doi. org/10.1038/nrdp.2017.16)

7 Patterson CC, Dahlquist GG, Gyurus E, Green A, Soltesz G \& EURODIAB Study Group. Incidence trends for childhood type 1 diabetes in Europe during 1989-2003 and predicted new cases 200520: a multicentre prospective registration study. Lancet 2009373 2027-2033. (https://doi.org/10.1016/S0140-6736(09)60568-7)

8 Chobot A, Polanska J, Brandt A, Deja G, Glowinska-Olszewska B, Pilecki O, Szadkowska A, Mysliwiec M \& Jarosz-Chobot P. Updated 24-year trend of Type 1 diabetes incidence in children in Poland reveals a sinusoidal pattern and sustained increase. Diabetic Medicine 201734 1252-1258. (https://doi.org/10.1111/dme.13345)

9 Mehers KL \& Gillespie KM. The genetic basis for type 1 diabetes. British Medical Bulletin 200888 115-129. (https://doi.org/10.1093/ bmb/ldn045)

10 Knip M, Virtanen SM \& Akerblom HK. Infant feeding and the risk of type 1 diabetes. American Journal of Clinical Nutrition 201091 1506S-1513S. (https://doi.org/10.3945/ajcn.2010.28701C)

11 Stene LC \& Rewers M. Immunology in the clinic review series; focus on type 1 diabetes and viruses: the enterovirus link to type 1 diabetes: critical review of human studies. Clinical and Experimental Immunology 2012168 12-23. (https://doi.org/10.1111/j.13652249.2011.04555.x)

12 Boerner BP \& Sarvetnick NE. Type 1 diabetes: role of intestinal microbiome in humans and mice. Annals of the New York Academy of Sciences 20111243 103-118. (https://doi.org/10.1111/j.17496632.2011.06340.x)

13 Atkinson MA, Eisenbarth GS \& Michels AW. Type 1 diabetes. Lancet 2014383 69-82. (https://doi.org/10.1016/S0140-6736(13)60591-7)

14 Gianani R, Campbell-Thompson M, Sarkar SA, Wasserfall C, Pugliese A, Solis JM, Kent SC, Hering BJ, West E, Steck A, et al. Dimorphic histopathology of long-standing childhood-onset diabetes. Diabetologia 201053 690-698. (https://doi.org/10.1007/ s00125-009-1642-y) 
15 Hawkes CJ, Schloot NC, Marks J, Willemen SJ, Drijfhout JW, Mayer EK, Christie MR \& Roep BO. T-cell lines reactive to an immunodominant epitope of the tyrosine phosphatase-like autoantigen IA-2 in type 1 diabetes. Diabetes $200049356-366$ (https://doi.org/10.2337/diabetes.49.3.356)

16 Lohmann T, Leslie RD, Hawa M, Geysen M, Rodda S \& Londei M. Immunodominant epitopes of glutamic acid decarboxylase 65 and 67 in insulin-dependent diabetes mellitus. Lancet 1994343 1607-1608. (https://doi.org/10.1016/s0140-6736(94)93061-9)

17 Naquet P, Ellis J, Tibensky D, Kenshole A, Singh B, Hodges R \& Delovitch TL. T cell autoreactivity to insulin in diabetic and related non-diabetic individuals. Journal of Immunology 1988140 2569-2578.

18 Willcox A, Richardson SJ, Bone AJ, Foulis AK \& Morgan NG. Analysis of islet inflammation in human type 1 diabetes. Clinical and Experimental Immunology 2009155 173-181. (https://doi. org/10.1111/j.1365-2249.2008.03860.x)

19 Sheehy DF, Quinnell SP \& Vegas AJ. Targeting Type 1 diabetes: selective approaches for new therapies. Biochemistry $20195 \mathbf{5 8}$ 214-233. (https://doi.org/10.1021/acs.biochem.8b01118)

20 Insel RA, Dunne JL, Atkinson MA, Chiang JL, Dabelea D, Gottlieb PA, Greenbaum CJ, Herold KC, Krischer JP, Lernmark A, et al. Staging presymptomatic Type 1 diabetes: a scientific statement of JDRF, the Endocrine Society, and the American Diabetes Association. Diabetes Care 201538 1964-1974. (https://doi. org/10.2337/dc15-1419)

21 Doggrell SA. Do glucagon-like peptide-1 receptor (GLP-1R) agonists have potential as adjuncts in the treatment of type 1 diabetes? Expert Opinion on Pharmacotherapy 201819 1655-1661. (https://doi.org/10.1 080/14656566.2018.1519547)

22 DiMeglio LA, Evans-Molina C \& Oram RA. Type 1 diabetes. Lancet 2018 391 2449-2462. (https://doi.org/10.1016/S0140-6736(18)31320-5)

23 Nathan DM \& DCCT/EDIC Research Group. The diabetes control and complications trial/epidemiology of diabetes interventions and complications study at 30 years: overview. Diabetes Care 201437 9-16. (https://doi.org/10.2337/dc13-2112)

24 Rosengren A, Vestberg D, Svensson AM, Kosiborod M, Clements M, Rawshani A, Pivodic A, Gudbjornsdottir S \& Lind M. Long-term excess risk of heart failure in people with type 1 diabetes: a prospective case-control study. Lancet: Diabetes and Endocrinology 20153 876-885. (https://doi.org/10.1016/S2213-8587(15)00292-2)

25 Thorel F, Népote V, Avril I, Kohno K, Desgraz R, Chera S \& Herrera PL. Conversion of adult pancreatic alpha-cells to beta-cells after extreme beta-cell loss. Nature 2010464 1149-1154. (https://doi. $\operatorname{org} / 10.1038 /$ nature08894)

26 Chera S, Baronnier D, Ghila L, Cigliola V, Jensen JN, Gu G, Furuyama K, Thorel F, Gribble FM, Reimann F, et al. Diabetes recovery by age-dependent conversion of pancreatic $\delta$-cells into insulin producers. Nature 2014514 503-507. (https://doi. $\operatorname{org} / 10.1038 /$ nature13633)

27 Montanya E, Nacher V, Biarnes M \& Soler J. Linear correlation between beta-cell mass and body weight throughout the lifespan in Lewis rats: role of beta-cell hyperplasia and hypertrophy. Diabetes 200049 1341-1346. (https://doi.org/10.2337/diabetes.49.8.1341)

28 Wang P, Alvarez-Perez JC, Felsenfeld DP, Liu H, Sivendran S, Bender A, Kumar A, Sanchez R, Scott DK, Garcia-Ocaña A, et al. A high-throughput chemical screen reveals that harminemediated inhibition of DYRK1A increases human pancreatic beta cell replication. Nature Medicine 201521 383-388. (https://doi. org/10.1038/nm.3820)

29 Dirice E, Walpita D, Vetere A, Meier BC, Kahraman S, Hu J, Dancik V, Burns SM, Gilbert TJ, Olson DE, et al. Inhibition of DYRK1A stimulates human beta-cell proliferation. Diabetes $2016 \mathbf{6 5}$ 1660-1671. (https://doi.org/10.2337/db15-1127)

30 Christakos S, Dhawan P, Verstuyf A, Verlinden L \& Carmeliet G. Vitamin D: metabolism, molecular mechanism of action, and pleiotropic effects. Physiological Reviews 201696 365-408. (https:// doi.org/10.1152/physrev.00014.2015)

31 Gatti D, Idolazzi L \& Fassio A. Vitamin D: not just bone, but also immunity. Minerva Medica 2016107 452-460.

32 Wang Y, Zhu J \& DeLuca HF. Where is the vitamin D receptor? Archives of Biochemistry and Biophysics 2012523 123-133. (https:// doi.org/10.1016/j.abb.2012.04.001)

33 Cannell JJ, Hollis BW, Zasloff M \& Heaney RP. Diagnosis and treatment of vitamin D deficiency. Expert Opinion on Pharmacotherapy 20089 107-118. (https://doi. org/10.1517/14656566.9.1.107)

34 Overbergh L, Decallonne B, Valckx D, Verstuyf A, Depovere J, Laureys J, Rutgeerts O, Saint-Arnaud R, Bouillon R \& Mathieu C. Identification and immune regulation of 25-hydroxyvitamin D-1alpha-hydroxylase in murine macrophages. Clinical and Experimental Immunology 2000120 139-146. (https://doi.org/10.1046/j.13652249.2000.01204.x)

35 Bland R, Markovic D, Hills CE, Hughes SV, Chan SL, Squires PE \& Hewison M. Expression of 25-hydroxyvitamin D3-1alphahydroxylase in pancreatic islets. Journal of Steroid Biochemistry and Molecular Biology 2004 89-90 121-125. (https://doi.org/10.1016/j. jsbmb.2004.03.115)

36 Mathis D, Vence L \& Benoist C. $\beta$-Cell death during progression to diabetes. Nature 2001414 792-798. (https://doi. $\operatorname{org} / 10.1038 / 414792 a)$

37 Mauf S, Penna-Martinez M, Jentzsch T, Ackermann H, Henrich D, Radeke HH, Brück P, Badenhoop K \& Ramos-Lopez E. Immunomodulatory effects of 25-hydroxyvitamin D3 on monocytic cell differentiation and influence of vitamin D3 polymorphisms in type 1 diabetes. Journal of Steroid Biochemistry and Molecular Biology 2015147 17-23. (https://doi.org/10.1016/j.jsbmb.2014.11.001)

38 Penna G \& Adorini L. 1 $\alpha, 25$-Dihydroxyvitamin D3 inhibits differentiation, maturation, activation, and survival of dendritic cells leading to impaired alloreactive T cell activation. Journal of Immunology 2000164 2405-2411. (https://doi.org/10.4049/ jimmunol.164.5.2405)

39 Szymczak I \& Pawliczak R. The active metabolite of vitamin D3 as a potential immunomodulator. Scandinavian Journal of Immunology 201683 83-91. (https://doi.org/10.1111/sji.12403)

40 D'Ambrosio D, Cippitelli M, Cocciolo MG, Mazzeo D, Di Lucia P, Lang R, Sinigaglia F \& Panina-Bordignon P. Inhibition of IL-12 production by 1,25-dihydroxyvitamin D3. Involvement of NF-kappaB downregulation in transcriptional repression of the $\mathrm{p} 40$ gene. Journal of Clinical Investigation 1998101 252-262. (https://doi. org/10.1172/JCI1050)

41 Farias AS, Spagnol GS, Bordeaux-Rego P, Oliveira COF, Fontana AGM, de Paula RFO, Santos MPA, Pradella F, Moraes AS, Oliveira EC, et al. Vitamin D3 induces IDO+ tolerogenic DCs and enhances Treg, reducing the severity of EAE. CNS Neuroscience and Therapeutics 201319 269-277. (https://doi.org/10.1111/ cns.12071)

42 van der Aar AMG, Sibiryak DS, Bakdash G, van Capel TMM, van der Kleij HPM, Opstelten D-JE, Teunissen MBM, Kapsenberg ML \& de Jong EC. Vitamin D3 targets epidermal and dermal dendritic cells for induction of distinct regulatory T cells. Journal of Allergy and Clinical Immunology 2011127 1532.e1537-1540.e1537. (https://doi. org/10.1016/j.jaci.2011.01.068)

43 Chen J, Bruce D \& Cantorna MT. Vitamin D receptor expression controls proliferation of naïve CD8+ T cells and development of CD8 mediated gastrointestinal inflammation. BMC Immunology 201415 6-6. (https://doi.org/10.1186/1471-2172-15-6)

44 Lysandropoulos AP, Jaquiéry E, Jilek S, Pantaleo G, Schluep M \& Du Pasquier RA. Vitamin D has a direct immunomodulatory effect on CD8+ T cells of patients with early multiple sclerosis and healthy control subjects. Journal of Neuroimmunology 2011233 240-244. (https://doi.org/10.1016/j.jneuroim.2010.11.008) 
45 Piantoni S, Andreoli L, Scarsi M, Zanola A, Dall'Ara F, Pizzorni C, Cutolo M, Airò P \& Tincani A. Phenotype modifications of T-cells and their shift toward a Th2 response in patients with systemic lupus erythematosus supplemented with different monthly regimens of vitamin D. Lupus 201524 490-498. (https://doi. org/10.1177/0961203314559090)

46 Colin EM, Asmawidjaja PS, van Hamburg JP, Mus AMC, van Driel M, Hazes JMW, van Leeuwen JPTM \& Lubberts E. 1,25-Dihydroxyvitamin D3 modulates Th17 polarization and interleukin-22 expression by memory T cells from patients with early rheumatoid arthritis. Arthritis and Rheumatism 201062 132-142. (https://doi.org/10.1002/art.25043)

47 Neve A, Corrado A \& Cantatore FP. Immunomodulatory effects of vitamin D in peripheral blood monocyte-derived macrophages from patients with rheumatoid arthritis. Clinical and Experimental Medicine 201414 275-283. (https://doi.org/10.1007/s10238-0130249-2)

48 Zhang X, Zhou M, Guo Y, Song Z \& Liu B. 1,25-Dihydroxyvitamin $\mathrm{D}_{3}$ promotes high glucose-induced M1 macrophage switching to M2 via the VDR-PPAR $\gamma$ signaling pathway. BioMed Research International 2015 2015 157834. (https://doi.org/10.1155/2015/157834)

49 Korf H, Wenes M, Stijlemans B, Takiishi T, Robert S, Miani M, Eizirik DL, Gysemans C \& Mathieu C. 1,25-Dihydroxyvitamin D3 curtails the inflammatory and T cell stimulatory capacity of macrophages through an IL-10-dependent mechanism. Immunobiology 2012217 1292-1300. (https://doi.org/10.1016/j. imbio.2012.07.018)

50 Chen S, Sims GP, Chen XX, Gu YY, Chen S \& Lipsky PE. Modulatory effects of 1,25-dihydroxyvitamin D3 on human B cell differentiation. Journal of Immunology 2007179 1634-1647. (https://doi.org/10.4049/ jimmunol.179.3.1634)

51 Lemire JM, Adams JS, Sakai R \& Jordan SC. 1alpha,25Dihydroxyvitamin D3 suppresses proliferation and immunoglobulin production by normal human peripheral blood mononuclear cells. Journal of Clinical Investigation 198474 657-661. (https://doi. org/10.1172/JCI111465)

52 Heine G, Niesner U, Chang HD, Steinmeyer A, Zügel U, Zuberbier T, Radbruch A \& Worm M. 1,25-Dihydroxyvitamin D(3) promotes IL-10 production in human B cells. European Journal of Immunology 200838 2210-2218. (https://doi.org/10.1002/eji.200838216)

53 Drozdenko G, Scheel T, Heine G, Baumgrass R \& Worm M. Impaired $\mathrm{T}$ cell activation and cytokine production by calcitriol-primed human B cells. Clinical and Experimental Immunology $2014 \mathbf{1 7 8}$ 364-372. (https://doi.org/10.1111/cei.12406)

54 Mathieu C, Waer M, Laureys J, Rutgeerts O \& Bouillon R. Prevention of autoimmune diabetes in NOD mice by 1,25 dihydroxyvitamin D3. Diabetologia 199437 552-558. (https://doi.org/10.1007/BF00403372)

55 Gregori S, Giarratana N, Smiroldo S, Uskokovic M \& Adorini L. A 1,25-dihydroxyvitamin D3 analog enhances regulatory T-cells and arrests autoimmune diabetes in NOD mice. Diabetes $2002 \mathbf{5 1}$ 1367-1374. (https://doi.org/10.2337/diabetes.51.5.1367)

56 Zella JB, McCary LC \& DeLuca HF. Oral administration of 1,25-dihydroxyvitamin D3 completely protects NOD mice from insulin-dependent diabetes mellitus. Archives of Biochemistry and Biophysics 2003417 77-80. (https://doi.org/10.1016/s00039861(03)00338-2)

57 Zeitz U, Weber K, Soegiarto DW, Wolf E, Balling R \& Erben RG. Impaired insulin secretory capacity in mice lacking a functional vitamin D receptor. FASEB Journal 200317 509-511. (https://doi. org/10.1096/fj.02-0424fje)

58 Giulietti A, Gysemans C, Stoffels K, van Etten E, Decallonne B, Overbergh L, Bouillon R \& Mathieu C. Vitamin D deficiency in early life accelerates Type 1 diabetes in non-obese diabetic mice. Diabetologia 200447 451-462. (https://doi.org/10.1007/s00125-004-1329-3)

59 Takiishi T, Ding L, Baeke F, Spagnuolo I, Sebastiani G, Laureys J, Verstuyf A, Carmeliet G, Dotta F, Van Belle TL, et al. Dietary supplementation with high doses of regular vitamin D3 safely reduces diabetes incidence in NOD mice when given early and long term. Diabetes 201463 2026-2036. (https://doi.org/10.2337/db13-1559)

60 Shaikh MN, Malapati BR, Gokani R, Patel B \& Chatriwala M. Serum magnesium and vitamin D levels as indicators of asthma severity. Pulmonary Medicine 20162016 1643717. (https://doi. org/10.1155/2016/1643717)

61 Al-Zubeidi H, Leon-Chi L \& Newfield RS. Low vitamin D level in pediatric patients with new onset type 1 diabetes is common, especially if in ketoacidosis. Pediatric Diabetes 201617 592-598. (https://doi.org/10.1111/pedi.12342)

62 Pozzilli P, Manfrini S, Crinò A, Picardi A, Leomanni C, Cherubini V, Valente L, Khazrai M, Visalli N \& IMDIAB group. Low levels of 25-hydroxyvitamin D3 and 1,25-dihydroxyvitamin D3 in patients with newly diagnosed type 1 diabetes. Hormone and Metabolic Research 200537 680-683. (https://doi.org/10.1055/s-2005-870578)

63 Rasoul MA, Al-Mahdi M, Al-Kandari H, Dhaunsi GS \& Haider MZ. Low serum vitamin-D status is associated with high prevalence and early onset of type-1 diabetes mellitus in Kuwaiti children. BMC Pediatrics 201616 95-95. (https://doi.org/10.1186/ s12887-016-0629-3)

64 Greer RM, Portelli SL, Hung BS-M, Cleghorn GJ, McMahon SK, Batch JA \& Conwell LS. Serum vitamin D levels are lower in Australian children and adolescents with type 1 diabetes than in children without diabetes. Pediatric Diabetes 201314 31-41. (https:// doi.org/10.1111/j.1399-5448.2012.00890.x)

65 Hyppönen E, Laara E, Reunanen A, Jarvelin MR \& Virtanen SM. Intake of vitamin $\mathrm{D}$ and risk of type 1 diabetes: a birth-cohort study. Lancet 2001358 1500-1503. (https://doi.org/10.1016/S01406736(01)06580-1)

66 Dong JY, Zhang WG, Chen JJ, Zhang ZL, Han SF \& Qin LQ. Vitamin $\mathrm{D}$ intake and risk of type 1 diabetes: a meta-analysis of observational studies. Nutrients 20135 3551-3562. (https://doi.org/10.3390/ nu5093551)

67 Aljabri KS, Bokhari SA \& Khan MJ. Glycemic changes after vitamin D supplementation in patients with type 1 diabetes mellitus and vitamin D deficiency. Annals of Saudi Medicine 201030 454-458. (https://doi.org/10.4103/0256-4947.72265)

68 Bogdanou D, Penna-Martinez M, Filmann N, Chung TL, MoranAuth Y, Wehrle J, Cappel C, Huenecke S, Herrmann E, Koehl U, et al. T-lymphocyte and glycemic status after vitamin D treatment in type 1 diabetes: a randomized controlled trial with sequential crossover. Diabetes/Metabolism Research and Reviews 201733 e2865. (https://doi. org/10.1002/dmrr.2865)

69 Gabbay MAL, Sato MN, Finazzo C, Duarte AJS \& Dib SA. Effect of cholecalciferol as adjunctive therapy with insulin on protective immunologic profile and decline of residual $\beta$-cell function in new-onset type 1 diabetes mellitus. Archives of Pediatrics and Adolescent Medicine 2012166 601-607. (https://doi.org/10.1001/ archpediatrics.2012.164)

70 Pitocco D, Crino A, Di Stasio E, Manfrini S, Guglielmi C, Spera S, Anguissola GB, Visalli N, Suraci C, Matteoli MC, et al. The effects of calcitriol and nicotinamide on residual pancreatic $\beta$-cell function in patients with recent-onset Type 1 diabetes (IMDIAB XI). Diabetic Medicine 200623 920-923. (https://doi.org/10.1111/j.14645491.2006.01921.x)

71 Bizzarri C, Pitocco D, Napoli N, Di Stasio E, Maggi D, Manfrini S, Suraci C, Cavallo MG, Cappa M, Ghirlanda G, et al. No protective effect of calcitriol on beta-cell function in recent-onset type 1 diabetes: the IMDIAB XIII trial. Diabetes Care 201033 1962-1963. (https://doi.org/10.2337/dc10-0814)

72 Walter M, Kaupper T, Adler K, Foersch J, Bonifacio E \& Ziegler AG. No effect of the 1alpha,25-dihydroxyvitamin D3 on beta-cell residual function and insulin requirement in adults with new-onset type 1 diabetes. Diabetes Care 201033 1443-1448. (https://doi.org/10.2337/ dc09-2297)

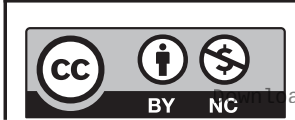

This work is licensed under a Creative Commons Attribution-NonCommercial 4.0 International License. ded from Bioscientifica com at 04/26/2023 12:12:34PM 
73 Ataie-Jafari A, Loke SC, Rahmat AB, Larijani B, Abbasi F, Leow MKS \& Yassin Z. A randomized placebo-controlled trial of alphacalcidol on the preservation of beta cell function in children with recent onset type 1 diabetes. Clinical Nutrition 201332 911-917. (https://doi. org/10.1016/j.clnu.2013.01.012)

74 Giarratana N, Penna G, Amuchastegui S, Mariani R, Daniel KC \& Adorini L. A vitamin D analog down-regulates proinflammatory chemokine production by pancreatic islets inhibiting $\mathrm{T}$ cell recruitment and Type 1 diabetes development. Journal of Immunology 2004173 2280-2287. (https://doi.org/10.4049/jimmunol.173.4.2280)

75 Van Belle TL, Vanherwegen AS, Feyaerts D, De Clercq P, Verstuyf A Korf H, Gysemans C \& Mathieu C. 1,25-Dihydroxyvitamin D3 and its analog TX527 promote a stable regulatory T cell phenotype in T cells from Type 1 diabetes patients. PLoS ONE 20149 e109194. (https://doi.org/10.1371/journal.pone.0109194)

76 Federico G, Focosi D, Marchi B, Randazzo E, De Donno M, Vierucci F, Bugliani M, Campi F, Scatena F, Saggese G, et al. Administering 25-hydroxyvitamin D3 in vitamin D-deficient young type 1A diabetic patients reduces reactivity against islet autoantigens Clinical Nutrition 201433 1153-1156. (https://doi.org/10.1016/j. clnu.2014.01.001)

77 Jeng L, Yamshchikov AV, Judd SE, Blumberg HM, Martin GS, Ziegler TR \& Tangpricha V. Alterations in vitamin D status and antimicrobial peptide levels in patients in the intensive care unit with sepsis. Journal of Translational Medicine 20097 28-28. (https://doi. org/10.1186/1479-5876-7-28)

78 Zanetti M, Gennaro R \& Romeo D. Cathelicidins: a novel protein family with a common proregion and a variable C-terminal antimicrobial domain. FEBS Letters 1995374 1-5. (https://doi. org/10.1016/0014-5793(95)01050-o)

79 Ramos R, Domingues L \& Gama M. LL37, a human antimicrobial peptide with immunomodulatory properties. In Science against Microbial Pathogens: Communicating Current Research and Technological Advances, Vol. 1. Ed A Mendez-Vilas. Badajoz: Formatex Research Center, 2011

80 Vandamme D, Landuyt B, Luyten W \& Schoofs L. A comprehensive summary of LL-37, the factotum human cathelicidin peptide. Cellular Immunology 2012280 22-35. (https://doi.org/10.1016/j. cellimm.2012.11.009)

81 Mansour SC, Pena OM \& Hancock RE. Host defense peptides: frontline immunomodulators. Trends in Immunology 201435 443-450. (https://doi.org/10.1016/j.it.2014.07.004)

82 Zasloff M. Antimicrobial peptides of multicellular organisms. Nature 2002415 389-395. (https://doi.org/10.1038/415389a)

83 Lee CC, Sun Y, Qian S \& Huang HW. Transmembrane pores formed by human antimicrobial peptide LL-37. Biophysical Journal $2011 \mathbf{1 0 0}$ 1688-1696. (https://doi.org/10.1016/j.bpj.2011.02.018)

84 Sorensen OE, Follin P, Johnsen AH, Calafat J, Tjabringa GS, Hiemstra PS \& Borregaard N. Human cathelicidin, hCAP-18, is processed to the antimicrobial peptide LL-37 by extracellular cleavage with proteinase 3. Blood 200197 3951-3959. (https://doi. org/10.1182/blood.v97.12.3951)

85 Agier J, Efenberger M \& Brzezinska-Blaszczyk E. Cathelicidin impact on inflammatory cells. Central-European Journal of Immunology 2015 40 225-235. (https://doi.org/10.5114/ceji.2015.51359)

86 Ciornei CD, Sigurdardottir T, Schmidtchen A \& Bodelsson M. Antimicrobial and chemoattractant activity, lipopolysaccharide neutralization, cytotoxicity, and inhibition by serum of analogs of human cathelicidin LL-37. Antimicrobial Agents and Chemotherapy 2005 49 2845-2850. (https://doi.org/10.1128/AAC.49.7.2845-2850.2005)

87 Lowry MB, Guo C, Borregaard N \& Gombart AF. Regulation of the human cathelicidin antimicrobial peptide gene by 1alpha,25dihydroxyvitamin D3 in primary immune cells. Journal of Steroid Biochemistry and Molecular Biology 2014143 183-191. (https://doi. org/10.1016/j.jsbmb.2014.02.004)
88 Wang TT, Nestel FP, Bourdeau V, Nagai Y, Wang Q, Liao J, TaveraMendoza L, Lin R, Hanrahan JW, Mader S, et al. Cutting edge: 1,25-dihydroxyvitamin D3 is a direct inducer of antimicrobial peptide gene expression. Journal of Immunology 2004173 2909-2912. (https://doi.org/10.4049/jimmunol.173.5.2909)

89 Dixon BM, Barker T, McKinnon T, Cuomo J, Frei B, Borregaard N \& Gombart AF. Positive correlation between circulating cathelicidin antimicrobial peptide (hCAP18/LL-37) and 25-hydroxyvitamin D levels in healthy adults. BMC Research Notes 20125 575-575. (https://doi.org/10.1186/1756-0500-5-575)

90 Gombart AF, Borregaard N \& Koeffler HP. Human cathelicidin antimicrobial peptide (CAMP) gene is a direct target of the vitamin D receptor and is strongly up-regulated in myeloid cells by 1,25-dihydroxyvitamin D3. FASEB Journal 200519 1067-1077. (https://doi.org/10.1096/fj.04-3284com)

91 Gombart AF, Saito T \& Koeffler HP. Exaptation of an ancient Alu short interspersed element provides a highly conserved vitamin D-mediated innate immune response in humans and primates. BMC Genomics 200910 321-321. (https://doi.org/10.1186/1471-2164-10-321)

92 Zhou X, Zhang P, Wang Q, Xia S, Ji N, Ding Y \& Wang Q. 25-Hydroxyvitamin D3 alleviates experimental periodontitis via promoting expression of cathelicidin in mice with Type 2 diabetic mellitus. Journal of Nutritional Science and Vitaminology $20186 \mathbf{4}$ 307-315. (https://doi.org/10.3177/jnsv.64.307)

93 Lowry MB, Guo C, Zhang Y, Fantacone ML, Logan IE, Campbell Y, Zhang W, Le M, Indra AK, Ganguli-Indra G, et al. A mouse model for vitamin D-induced human cathelicidin antimicrobial peptide gene expression. Journal of Steroid Biochemistry and Molecular Biology 2020 198105552 doi:10.1016/j.jsbmb.2019.105552.

94 Diana J, Simoni Y, Furio L, Beaudoin L, Agerberth B, Barrat F \& Lehuen A. Crosstalk between neutrophils, B-1a cells and plasmacytoid dendritic cells initiates autoimmune diabetes. Nature Medicine 201319 65-73. (https://doi.org/10.1038/nm.3042)

95 Lande R, Ganguly D, Facchinetti V, Frasca L, Conrad C, Gregorio J, Meller S, Chamilos G, Sebasigari R, Riccieri V, et al. Neutrophils activate plasmacytoid dendritic cells by releasing self-DNApeptide complexes in systemic lupus erythematosus. Science Translational Medicine 20113 73ra19. (https://doi.org/10.1126/ scitranslmed.3001180)

96 Döring Y, Manthey HD, Drechsler M, Lievens D, Megens RT, Soehnlein O, Busch M, Manca M, Koenen RR, Pelisek J, et al. Autoantigenic protein-DNA complexes stimulate plasmacytoid dendritic cells to promote atherosclerosis. Circulation 2012125 1673-1683. (https://doi.org/10.1161/CIRCULATIONAHA.111.046755)

97 Brauner H, Luthje P, Grunler J, Ekberg NR, Dallner G, Brismar K \& Brauner A. Markers of innate immune activity in patients with type 1 and type 2 diabetes mellitus and the effect of the anti-oxidant coenzyme Q10 on inflammatory activity. Clinical and Experimental Immunology 2014177 478-482. (https://doi.org/10.1111/cei.12316)

98 Chawla H, Kar P, Saha S, Singh UB, Tandon N \& Goswami R. Circulating antimicrobial peptide LL-37 status in type 1 diabetes mellitus and its relation with glycemic control. Annals of the National Academy of Medical Sciences 201752 66-72. (https://doi. org/10.1055/s-0040-1712747)

99 Sun J, Furio L, Mecheri R, van der Does AM, Lundeberg E, Saveanu L, Chen Y, van Endert P, Agerberth B \& Diana J. Pancreatic beta-cells limit autoimmune diabetes via an immunoregulatory antimicrobial peptide expressed under the influence of the gut microbiota. Immunity 201543 304-317. (https://doi.org/10.1016/j.immuni.2015.07.013)

100 Patrick C, Wang GS, Lefebvre DE, Crookshank JA, Sonier B, Eberhard C, Mojibian M, Kennedy CR, Brooks SP, Kalmokoff ML, et al. Promotion of autoimmune diabetes by cereal diet in the presence or absence of microbes associated with gut immune activation, regulatory imbalance, and altered cathelicidin antimicrobial peptide. Diabetes 201362 2036-2047. (https://doi.org/10.2337/db12-1243) https://ec.bioscientifica.com https://doi.org/10.1530/EC-20-0484 (c) 2021 The authors Published by Bioscientifica Ltd

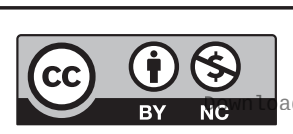

This work is licensed under a Creative Commons Attribution-NonCommercial 4.0 International License. ded from Bioscientifica.com at 04/26/2023 12:12:34PM 
101 Sun J, Xu M, Ortsater H, Lundeberg E, Juntti-Berggren L, Chen YQ Haeggstrom JZ, Gudmundsson GH, Diana J \& Agerberth B. Cathelicidins positively regulate pancreatic beta-cell functions. FASEB Journal 201630 884-894. (https://doi.org/10.1096/fj.15-275826)

102 Pound LD, Patrick C, Eberhard CE, Mottawea W, Wang GS, Abujamel T, Vandenbeek R, Stintzi A \& Scott FW. Cathelicidin antimicrobial peptide: a novel regulator of islet function, islet regeneration, and selected gut bacteria. Diabetes 201564 4135-4147. (https://doi.org/10.2337/db15-0788)

103 Ahuja M, Schwartz DM, Tandon M, Son A, Zeng M, Swaim W, Eckhaus M, Hoffman V, Cui Y, Xiao B, et al. Orai1-mediated antimicrobial secretion from pancreatic acini shapes the gut microbiome and regulates gut innate immunity. Cell Metabolism 2017 25 635-646. (https://doi.org/10.1016/j.cmet.2017.02.007)
104 Tilg H \& Adolph TE. Beyond digestion: the pancreas shapes intestinal microbiota and immunity. Cell Metabolism 201725 495-496. (https://doi.org/10.1016/j.cmet.2017.02.018)

105 Deng YY, Shamoon M, He Y, Bhatia M \& Sun J. Cathelicidin-related antimicrobial peptide modulates the severity of acute pancreatitis in mice. Molecular Medicine Reports 201613 3881-3885. (https://doi. org/10.3892/mmr.2016.5008)

106 Gibson CC, Davis CT, Zhu W, Bowman-Kirigin JA, Walker AE, Tai Z, Thomas KR, Donato AJ, Lesniewski LA \& Li DY. Dietary vitamin D and its metabolites non-genomically stabilize the endothelium. PLOS ONE 201510 e0140370. (https://doi.org/10.1371/journal.pone.0140370)

107 Stenwall A, Ingvast S, Skog O \& Korsgren O. Characterization of host defense molecules in the human pancreas. Islets 201911 89-101. (https://doi.org/10.1080/19382014.2019.1585165)

Received in final form 6 November 2020

Accepted 25 November 2020

Accepted Manuscript published online 27 November 2020
This work is licensed under a Creative Commons Attribution-NonCommercial 4.0 International License. ded from Bioscientifica.com at 04/26/2023 12:12:34PM 